\title{
HOW TO DATE NOTHING WITH COSMOGENIC NUCLIDES
}

\section{KAKO DATIRATI PRAZNINE S KOZMOGENIMI NUKLIDI}

\author{
Philipp HÄUSELMANN ${ }^{1}$
}

\begin{abstract}
UDC 539.16:552.5(494)

Philipp Häuselmann: How to date nothing with cosmogenic nuclides

A cave is a natural void in the rock. Therefore, a cave in itself cannot be dated, and one has to resort to datable sediments to get ideas about the age of the void itself. The problem then is that it is never very certain that the obtained age really is coincident with the true age of the cave. Here, we present the use of a method which couples sedimentary and morphologic information to get a relative chronology of events. Datings within this relative chronology can be used for assessing ages of forms, processes, and sediments, and the obtained dates also fix some milestones within the chronology, which then can be used to retrace, among other things, paleoclimatic variations. For many cave systems, the dating limits of the most widely used U/Th method on speleothems are too low (350 to max. $700 \mathrm{ka}$ ) to get ages that inform us about the age of the cave. The recent use of cosmogenic nuclides on quartz-containing sediment permits to push the datable range back to $5 \mathrm{Ma}$. While the theoretical background is explained elsewhere (Granger, this volume), we concentrate on the Siebenhengste example (Switzerland).
\end{abstract}

Key words: relative chronology, cosmogenic nuclides, cave dating methodology, Siebenhengste.
Izvleček

UDK 539.16:552.5(494)

Philipp Häuselmann: Kako datirati praznine s kozmogenimi nuklidi

Jame predstavljajo praznino v kamninski masi in jim kot takim ne moremo določiti starost. Zato z datiranjem jamskih sedimentov sklepamo tudi o starosti jame, pri čemer seveda ne moremo trditi, da je dobljena starost tudi prava starost jame. V članku predstavimo metodo pri kateri z združitvijo sedimentarnih in morfoloških izsledkov sklepamo o relativni kronologiji dogodkov. Datiranje v oviru relativne kronologije lahko uporabimo za določevanje starosti različnih oblik, procesov in sedimentov. Dobljene rezultate pa lahko uporabimo kot pomembne mejnike v kronologiji, npr. pri intepretaciji klimatskih sprememb. Veliko jam je starejšiih od zgornje meje starosti (350 do $700 \mathrm{ka}$ ), ki jo lahko določimo $\mathrm{z}$ uran-torijevo metodo, ki je zelo razširjena. $\mathrm{V}$ zadnjem času se zato uveljavlja metoda datacije s kozmogenimi nuklidi, ki omogoča datiranje dogodkov do starosti $5 \mathrm{Ma}$. Ker je teoretično ozadje te metode predstavljeno drugje (npr. Granger v tej številki), se tu omejimo le na uporabo metode v jamskem sistemu Siebenhengste (Švica).

Ključne besede: relativna kronologija, kozmogeni nuklidi, metodika datiranja jam, Siebenhengste.

\section{INTRODUCTION}

For many cave scientists, it might not be evident that a cave does not exist - only the surrounding rock gives existence to the void called cave. Therefore, a cave cannot be dated by conventional methods (Sasowsky 1998), but one has to use datable sediments. In karstic caves, the age of the surrounding rock gives a maximal age of the cave, while the sediments found within the cave give variable ages from today (in the case of still active speleothems) up to the last stages of speleogenesis (in the case of specific sand deposits dated by cosmogenic nuclides) and therefore to the age of nothing itself.

${ }^{1}$ Swiss Institute of Speleology and Karst studies SISKA, c.p. 818, 2301 La Chaux-de-Fonds, Switzerland, Fax 0041329133555 ,

e-mail: praezis@speleo.ch

Received/Prejeto: 11.12.2006 
This paper contains two parts. In the first part, the concept of relative chronology is explained. The link between morphology and sediment succession leads to a relative chronology of erosional and depositional events. Any dating of sediment with the purpose of studying the age of nothing basically requires such a relative chronology, which places the obtained data into a timeframe.

In the second part, the dating of sandy cave sediments with cosmogenic nuclides is briefly presented. Es- pecially when dealing with sands, a relative chronology is very important to date only meaningful sediments. The theoretical background is only very briefly presented, and the reader is referred to Granger (this volume) for more thorough information. The Siebenhengste example, the use of the relative chronology, and the obtained results are presented in more detail.

\section{THE CONCEPT OF RELATIVE CHRONOLOGY}

\section{INTRODUCTION}

Geologists and other scientists are usually aware of the laws of stratigraphy, which say that a younger sediment overlies an older one. These laws are the base of a relative chronology. This chronology is normally used to assess the correctness of an obtained age - the numerical value has to be concordant with stratigraphy, or the dated age may not be correct. Most of the time, this principle is used with stalagmites, where the obtained ages must be older at the base and younger at the top (e.g. Spötl et al. 2002).

Morphological indications, on the other hand, also give chronological information. A keyhole passage informs us that a phreatic phase was followed by a vadose one. Successions of speleogenetic phases are found in many cave systems. While some of them indicate base level rises (Audra et al., 2004), most of them indicate a downcutting of the regional base level (uplift, valley deepening, e.g. Ford \& Williams 1989; Rossi, Cortel \& Arcenegui 1997). This in itself is also a chronological information: the oldest cave passages are on top, the youngest ones near the present baselevel.

The difficulty now is to connect the sediments of several, basically independent, sedimentary profiles and to link them with the morphological succession of the cave passages. Thus, the sedimentary profiles are not independent from each other, and a relative chronology of erosional and depositional events over the whole cave can be made.

\section{EXAMPLE}

Figure 1 shows a real situation encountered in St. Beatus Cave (Switzerland):

To the right side is a typical keyhole passage which proves that a phreatic initiation of the ellipse on top was followed by a canyon incision. In the middle part of the figure, the meander gradually disappears and is replaced by a more or less elliptic passage that continues towards the left side of the figure. We see therefore a transition of a vadose feature into a phreatic one, and thus an old water level. In the profile to the right, we observe flowstone deposition that was truncated by the river incising the meander. Therefore, the flowstone predates the canyon, but postdates the initial genesis of the elliptic passage to the right. The meander changes into an elliptic passage, thus the two forms are contemporaneous. Consequently, the older flowstone disappears in the area of this transition. Within all the passages, silts were deposited. They are younger than the meander incision, and younger than the passage to the left, and prove of an inundation of the whole cave. Stalagmites grow on the silts and are partially still active. This example can be written as a table (Tab. 1).

Phreatic genesis of top ellipse
Deposition of flowstone
Erosion of flowstone
Erosion of meander
----- Water level lowering
Silt deposition
Stalagmite growth

Tab. 1: Chronology of erosional and depositional events (Fig. 1)

This table is a first relative chronology that links the sediments and the morphology of the cave.For practical reasons, the table presenting the chronology of events in a large cave system is not rewritten with each sedimentary succession found. Instead, the single sedimentary sequence is coupled with morphology, and is written as a column in the table. The next sedimentary sequence, again coupled with morphology, is written as another column. Thus, the above example would then look like Table 2 . 


\begin{tabular}{ll} 
Sequence at left & Sequence at right \\
\hline & $\begin{array}{l}\text { Phreatic genesis of top ellipse } \\
\text { Water level lowering }\end{array}$ \\
Phreatic genesis & $\begin{array}{l}\text { Deposition of flowstone } \\
\text { Erosion of flowstone }\end{array}$ \\
$\begin{array}{l}\text { Phreatic genesis } \\
\text { Phreatic genesis }\end{array}$ & Erosion of meander \\
Water level lowering & \\
Silt deposition & Silt deposition \\
Stalagmite growth & Stalagmite growth \\
\hline
\end{tabular}

Tab. 2: Chronological table with columnar writing of Fig. 1

\section{EXPANSION}

If we continue up- and downstream of that profile, we find several other morphological indications and sedimentary successions, each of them having a link with our initial profile - until we encounter the next paleo-waterlevel and thus the next morphological change. There, the links have to be established again. The table thus slowly grows and gets more complete.

Of course, the example presented above is an ideal case. Often, the passages lack some information, thus making it difficult to establish an unambiguous chron-

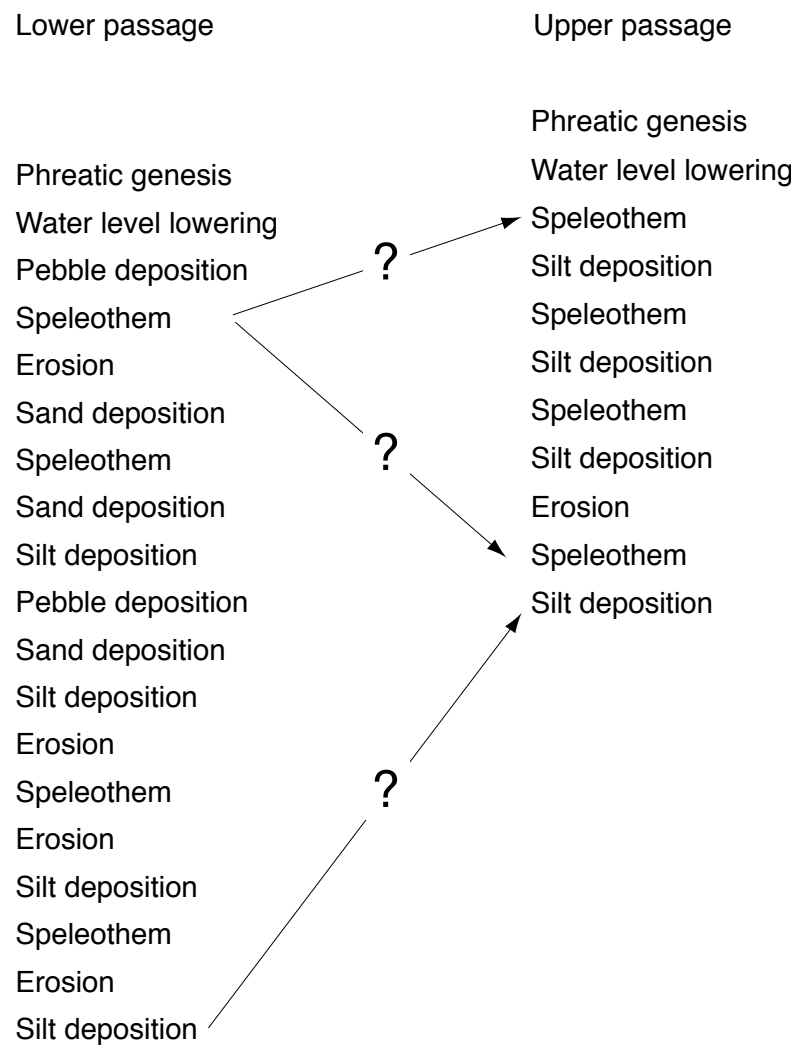

Tab. 3: A more complicated example from St. Beatus Cave

ological table. Table 3 give an example: here, the upper passage lacks incision of a canyon. Therefore, it is not clear whether the sediments found in the upper passage were all deposited while the lower passage was still in its initial genesis, or whether the sediments can be partly correlated. In this case, a relative correlation of the sediments by observation only is not possible: some absolute dates have to be obtained. Of course, these ages have to be in stratigraphic order of both the sediment succession and the morphologic indications. The above example had been dated by U/Th on speleothems. The resulting table is presented in Table 4. Here, the speleothems with roughly the same age have been grouped together. Then, laminated silt deposits that are thought to be a product of glacial damming (Bini, Tognini \& Zuccoli 1998; Audra et al., this volume), are parallelized, inferring that the whole cave was flooded in such conditions. Of course, some uncertainties still persist.

Lower passage

$\begin{array}{ll} & \begin{array}{l}\text { Phreatic genesis } \\ \text { Water level lowering } \\ \text { Speleothem (>350 ka) }\end{array} \\ \begin{array}{l}\text { Phreatic genesis } \\ \text { Water level lowering }\end{array} & \text { Silt deposition } \\ \text { Pebble deposition } & \\ \text { Speleothem } & \text { Speleothem (337 ka) } \\ \text { Erosion } & \\ \text { Sand deposition } \\ \text { Speleothem (235 ka) } \\ \text { Sand deposition } \\ \text { Silt deposition } \\ \text { Pebble deposition } \\ \text { Sand deposition } \\ \text { Silt deposition } \\ \text { Erosion } \\ \text { Speleothem (180 ka) } \\ \text { Erosion }\end{array}$

Tab. 4: The more complicated example, dated and expanded 


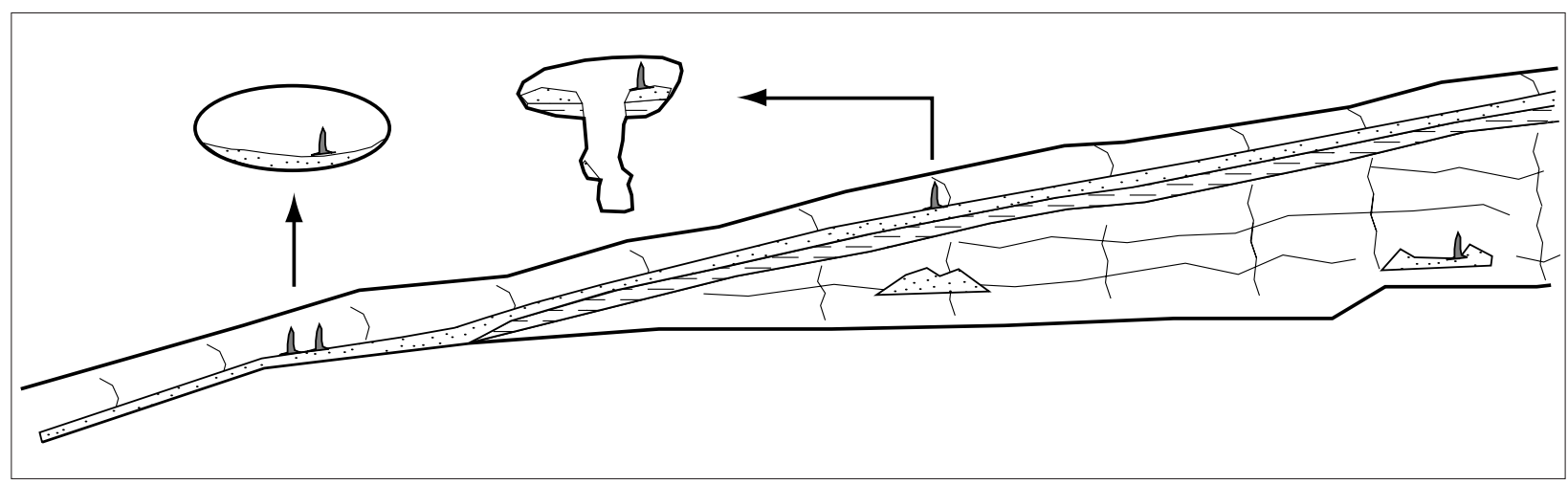

Fig. 1: Schematic section through a part of St. Beatus Cave (Switzerland), showing the relationship between sediments and morphology.

\section{WHY A RELATIVE CHRONOLOGY?}

The huge advantage of such a table of relative chronology is that it offers more control on the correct stratigraphic order than single sections, in ideal cases also the cave genesis can be dated, and last but not least, when having parallelized all the sedimentary sequences, it is possible to make a synthetic and dated sediment profile of the whole cave, which can then be used to get information on climatic variations and the presence or absence of glaciers damming the cave's exit (Häuselmann 2002).

\section{DATING WITH COSMOGENIC NUCLIDES}

\section{INTRODUCTION}

Cosmogenic nuclides are generated by the interaction of cosmic rays (mainly protons, neutrons, and muons) with atoms in the Earth's atmosphere and lithosphere. The production rate of cosmogenic isotopes depends on the intensity of the cosmic rays, which is subject to change. The atmosphere then absorbs most of the primary rays and thus causes production rates to depend on elevation. Finally, the geometry of the sample location (and eventual snow or soil cover) also has its effects. The radioactive nuclides most widely used for dating purposes are ${ }^{10} \mathrm{Be}$ and ${ }^{26} \mathrm{Al}$ produced in Quartz.

\section{THE PRINCIPLE AND POSSIBILITIES OF BURIAL DATING}

Burial dating of cave sediments is a relatively new technique that indicates the time sediment has been underground (Granger, Fabel \& Palmer 2001). It relays on the radioactive decay of the nuclides that were previously accumulated when the sediment was exposed at the surface. Whereas the intensity of the cosmic rays may vary with time, the ratio of produced ${ }^{10} \mathrm{Be}$ to ${ }^{26} \mathrm{Al}$ remains always approximately $1: 7$. The ${ }^{10} \mathrm{Be} /{ }^{26} \mathrm{Al}$ ratio can thus be calculated from the production rates and radioactive decay. If a sample that contains ${ }^{10} \mathrm{Be}$ and ${ }^{26} \mathrm{Al}$ is washed underground to sufficient depth to be shielded from further radiation, the nuclide concentrations diminish. Since ${ }^{26} \mathrm{Al}$ has a half-life of $720 \mathrm{ka}$, opposed to the one of ${ }^{10} \mathrm{Be}$ of $1.34 \mathrm{Ma}$, the ratio of $1: 7$ is gradually lowered. Measurement of that ratio therefore gives a direct indication of the time the sample remained underground.

Of course, several prerequisites have to be fulfilled in order to get a burial age:

- First of all, the sediment must contain quartz that was irradiated sufficiently prior to burial. The grain size should be minimally fine sand (otherwise the cleaning process also eliminates the quartz), but may reach pebble size without problem.

- Then, burial should ideally be $20-30 \mathrm{~m}$ below the surface to be sufficiently shielded from radiation.

- In order to make a measurement meaningful, the stratigraphic relationship of the sampled sand with the passage and other sediments should be clearly established - the relative chronology is needed.

Burial dating has a range from about 100'000 years up to $5 \mathrm{Ma}$. After that time, the amount of remaining isotopes is usually too small to be measured accurately (Granger \& Muzikar 2001). It is one of only a few radiometric methods that date lower Quarternary and Pliocene deposits. It is of great interest for cave dating, first because many old caves were created in the Pliocene or even earlier, and second because caves are very effective at shielding the sediment from further cosmic ray bombardment. As with other cave-dating methods, burial dating may also be used to date the age of the passage, 


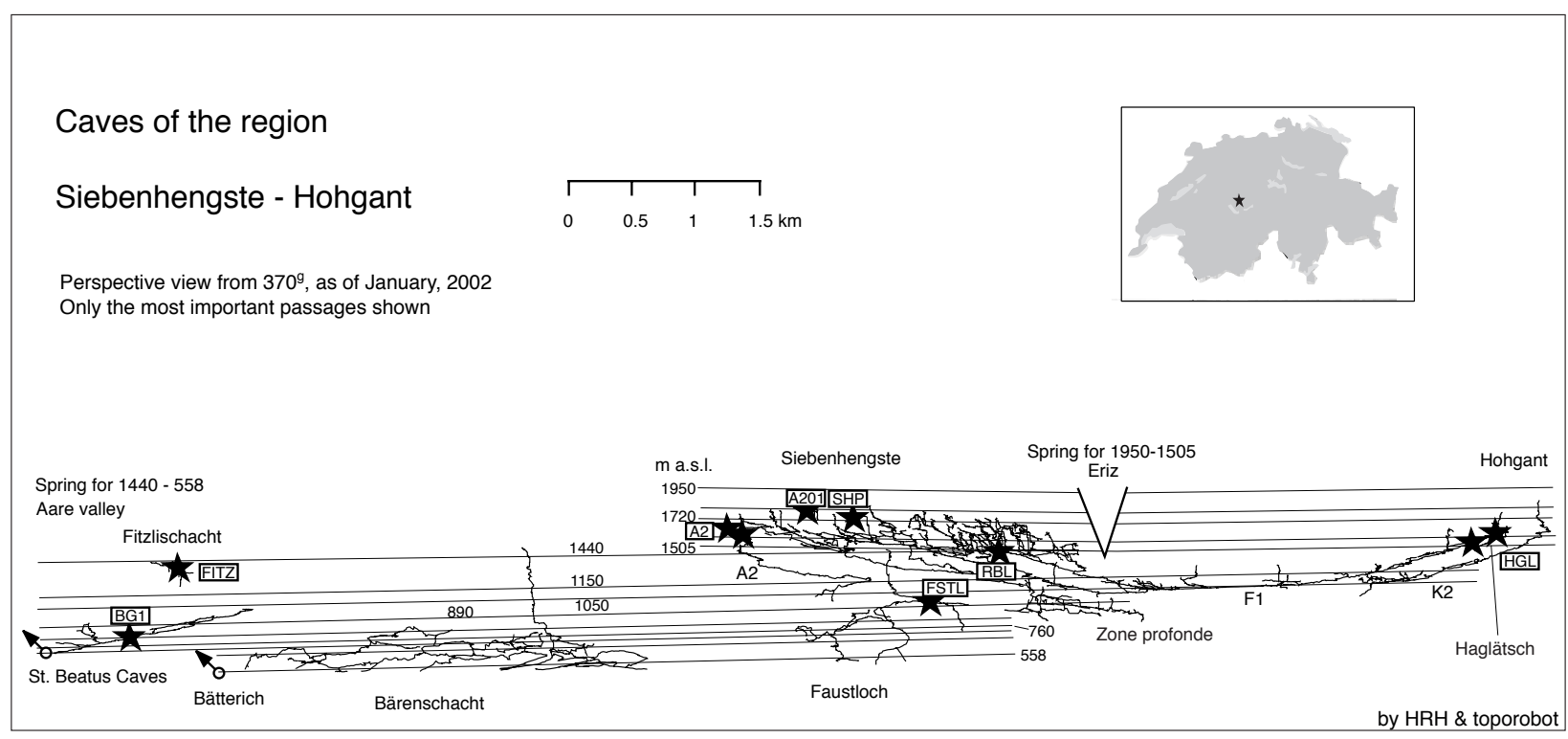

Fig. 2: Projection (370 degrees) of the Siebenhengste caves with the speleogenetic phases. Stars indicate sampling places for cosmogenic dates. From Häuselmann \& Granger (2005), modified.

thus indicating valley deepening rates and evolution of the surface outside the cave.

\section{THE SIEBENHENGSTE EXAMPLE}

We used burial dating to date the old passages of the Siebenhengste cave system in Switzerland. The Siebenhengste region is situated in the north-western part of the Alps, adjacent to the molasse basin. From Lake Thun, the mountain range extends to the Schrattenfluh, $20 \mathrm{~km}$ away. The cave region is one of the longest and deepest worldwide, with the Réseau Siebenhengste-Hohgant

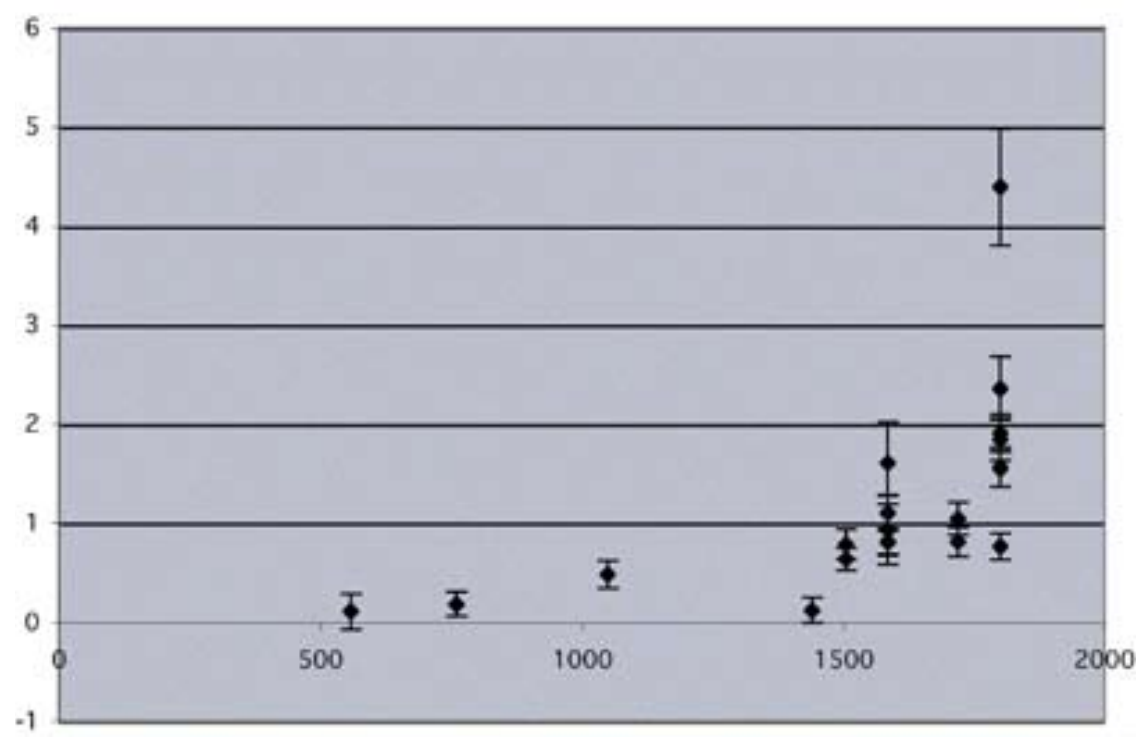

Fig. 3: Plot of ages (vertical) versus altitude (horizontal). having $154 \mathrm{~km}$ length and $-1340 \mathrm{~m}$ depth. The caves comprise 14 different speleogenetic phases, which can be related to paleo-valley bottoms (Jeannin, Bitterli \& Häuselmann 2000). The highest and oldest five phases (at presumed spring elevations of $>1900,1800,1720,1585$, and $1505 \mathrm{~m}$ a.s.l.) had their springs in the Eriz valley (Fig. 2). The next phase, at $1440 \mathrm{~m}$, shows a change in flow direction of $180^{\circ}$. The spring was then located in the area of Lake Thun. The influence of today's Aare valley (the site of Lake Thun today) therefore became predominant. All subsequent springs (at 1145, 1050, 890, 805, 760, 700, 660 , and $558 \mathrm{~m}$ a.s.l.) drained towards the Aare valley.

In the area between Lake Thun and Hohgant, a total of 23 sites were selected for sampling (see Fig. 2: stars indicate sites). Selection was made on the basis of a relative chronology, and care has been given to ensure that either the oldest possible sediment, or a series in stratigraphic order, was sampled. Due to the limited amount of time in which sampling could be done, the relative chronology is incomplete (Tab. 5), although the main events were retraced. 21 samples were analysed (Häuselmann \& Granger 2005). The results show a great diversity of ages, ranging from $118 \mathrm{ka}$ up to 


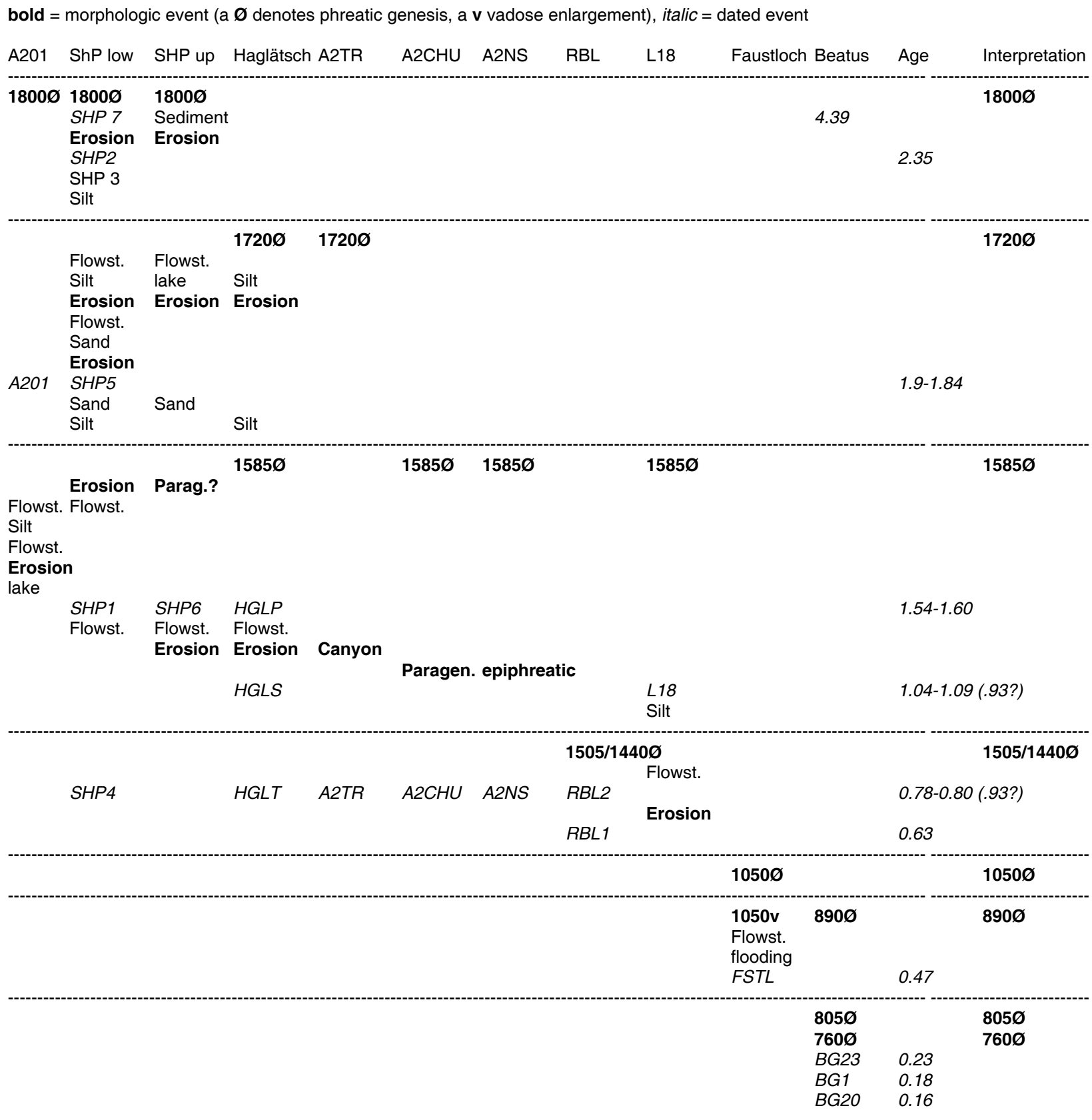

Tab. 5: Relative chronology of events around the Siebenhengste

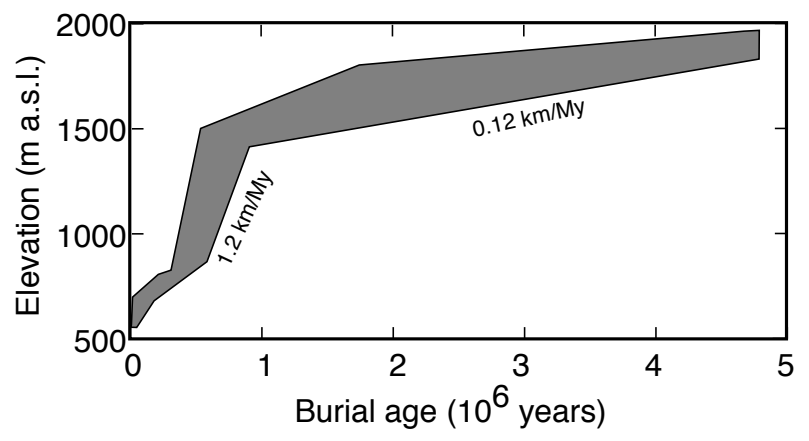

4.4 Ma (Tab. 6). The surface sample (MWA) has a burial age of $106 \pm 176 \mathrm{ka}$. Thus, the value is indistinguishable from zero, and we may assume that the sample was never buried. The sample from St. Beatus Cave (BG1) has an age of $182 \pm 122 \mathrm{ka}$. Its true value, bracketed by U/Th

Fig. 4: Rate of valley lowering in the Siebenhengste. Only maximum and minimum ages are displayed; however the valley deepening rates as well as the knickpoint at $\sim 800 \mathrm{ka}$ are easily visible. 


\begin{tabular}{|c|c|c|c|}
\hline Sample & Elevation & gge & error \\
\hline SHP7 & 1800 & 4.39 & 0.59 \\
\hline SHP2 & $1800^{\circ}$ & 2.36 & 0.32 \\
\hline $\mathrm{A} 201$ & $1800 !$ & 1.91 & 0.19 \\
\hline SHP5 & 1800 & 1. B 4 & 0.21 \\
\hline SHP1 & 1900 . & 1.57 & 0.20 \\
\hline SHFE & 1800 & 1.55 & 0.18 \\
\hline $\mathrm{SHP}_{4}$ & 1800 & 0.76 & 0.13 \\
\hline HGLS & 1720 & 1.05 & $0.1 \mathrm{~B}$ \\
\hline $\mathrm{A} 2 \mathrm{TA}$ & 1720 & 0.81 & 0.15 \\
\hline HCP & 1585 & 1.61 & 0.41 \\
\hline L 18 & 1565 & 1.10 & 0.18 \\
\hline HGLT & 1585 & 0.93 & 0.35 \\
\hline $\mathrm{A} 2 \mathrm{~N}$ & 1585 & 0.81 & 0.14 \\
\hline $\mathrm{AQCHU}$ & 1585 & 0.80 & 0.12 \\
\hline REL2 & 1505 & 0.78 & 0.15 \\
\hline RBL1 & 1505 & 0.64 & 0.11 \\
\hline FITZ & 1440 & 0.12 & 0.13 \\
\hline FSTL & 1050 & 0.48 & 0.14 \\
\hline BG1 & 760 & 0.78 & 0.12 \\
\hline WWA & 558 & 0.11 & 0.18 \\
\hline
\end{tabular}

ages, should be between 160 and $235 \mathrm{ka}$, which is again the case. These values indicate that the method yields young ages where expected.

A difficulty for dating with cosmogenic nuclides is mobility of the sediment. For instance, recent sand can be transported into a fossilized cave by a flood and then be deposited. Our results show that this process happens: for any speleogenetic phase, there is a range of ages observed (Fig. 3). However, Fig. 3 also indicates that the re-mobilization and re-deposition of old sediments is rarely observable: if this would be the case, we would expect a random distribution of ages throughout the phases. However, the maximum age decreases with the next lower phase. We can thus construct a gradual valley lowering with time which is represented in Fig. 4. We see a knickpoint in the line connecting the ages: this knickpoint occurs at around $800 \mathrm{ka}$ and $1500 \mathrm{~m}$. This point reflects a dramatic increase in valley deepening rate and coincides with the change in flow direction from Eriz to the Aare valley.

Tab. 6: Results of dating.

\section{CONCLUSIONS}

A relative chronology of events, albeit incomplete, coupled with burial age dating by cosmogenic nuclides, permitted to obtain a continuous history of valley incision in the Alps. Such data cannot be obtained in the same precision with other methods or at the surface. The results presented here are the first cosmogenic dates for an Alpine cave system in a glacially influenced area. The results indicate an onset of karstification in the Siebenhengste before 4.4 Ma, that is in the Pliocene or even earlier. Together with U/Th dates obtained earlier (Häuselmann 2002), the history of the Siebenhengste cave system and its surrounding environment can be traced back over a huge time span.

The construction of a complete relative chronology is very time-consuming, but can be extremely rewarding given the information one can extract from the cave. If speleogenetic phases, which are related to the overall geomorphic evolution of an area, can be expanded by such relative chronologies as well as absolute dates, the rate, duration, and extent of valley deepenings can be assessed, and a paleoclimatic history can be drawn as well. 


\section{REFERENCES}

Audra, Ph., L. Mocochain, H. Camus, E. Gilli, G. Clauzon \& J.-Y. Bigot, 2004: The effent of the Messinian Deep Stage on karst development around the Mediterranean Sea. Examples from Southern France. - Geodinamica Acta, 17, 6, 27-38.

Bini, A., P. Tognini, \& L. Zuccoli, 1998: Rapport entre karst et glaciers durant les glaciations dans les vallées préalpines du Sud des Alpes. - Karstologia, 32, 2, 7-26.

Ford, D.C. \& P. Williams, 1989: Karst geomorphology and hydrology. Chapman \& Hall, London, $601 \mathrm{p}$.

Granger, D.E, D. Fabel \& A.N. Palmer, 2001: PliocenePleistocene incision of the Green River, Kentucky, determined from radioactive decay of cosmogenic $26 \mathrm{Al}$ and 10Be in Mammoth Cave sediments. - GSA Bulletin, 113, 7, 825-836.

Granger, D.E. \& P.F. Muzikar, 2001: Dating sediment burial with in-situ produced cosmogenic nuclides: theory, techniques, and limitations. - Earth and Planetary Science Letters, 188, 269-281.

Häuselmann, Ph., 2002: Cave genesis and its relationship to surface processes: Investigations in the Siebenhengste region (BE, Switzerland). - $\mathrm{PhD}$ thesis, Université de Fribourg, 168 p.
Häuselmann, Ph. \& D.E. Granger, 2005: Dating of caves by cosmogenic nuclides: Method, possibilities, and the Siebenhengste example (Switzerland). - Acta Carsologica, 34, 1, 43-50.

Jeannin, P.-Y., T. Bitterli, T. \& Ph. Häuselmann, 2000: Genesis of a large cave system: the case study of the North of Lake Thun system (Canton Bern, Switzerland). In: A. Klimchouk, D. C. Ford, A. N. Palmer, \& W. Dreybrodt (Eds.), Speleogenesis: Evolution of Karst Aquifers, pp. 338-347.

Rossi, C., A. Cortel \& R. Arcenegui, 1997: Multiple paleo-water tables in Agujas Cave System (Sierra de Penalabra, Cantabrian Mountains, N Spain): Criteria for recognition and model for vertical evolution. - Proceedings 12th Int. Congress of Speleology, La Chaux-de-Fonds, Switzerland, 1, 183-187.

Sasowsky, I.D., 1998: Determining the age of what is not there. - Science, 279, 1874.

Spötl, C., M. Unterwurzacher, A. Mangini \& F.J. Longstaffe, 2002: Carbonate speleothems in the dry, inneralpine Vinschgau valley, northernmost Italy: Witnesses of changes in climate and hydrology since the last glacial maximum. - Journal of Sedimentary Research, 72, 6, 793-808 